\title{
REVIEW
}

\section{Advances in adrenal tumors 2018}

\author{
J Crona', F Beuschlein'2,3, K Pacak4 and B Skogseid' \\ 'Department of Medical Sciences, Uppsala University, Uppsala, Sweden \\ 2Medizinische Klinik und Poliklinik IV, Klinikum der Universität München, Munich, Germany \\ ${ }^{3}$ Klinik für Endokrinologie, Diabetologie und Klinische Ernährung, UniversitätsSpital Zürich, Zürich, Switzerland \\ 4Section on Medical Neuroendocrinology, Eunice Kennedy Shriver National Institute of Child Health \& Human Development, National Institutes of \\ Health, Bethesda, Maryland, USA
}

Correspondence should be addressed to J Crona: joakim.crona@medsci.uu.se

\begin{abstract}
This review aims to provide clinicians and researchers with a condensed update on the most important studies in the field during 2017. We present the academic output measured by active clinical trials and peer-reviewed published manuscripts. The most important and contributory manuscripts were summarized for each diagnostic entity, with a particular focus on manuscripts that describe translational research that have the potential to improve clinical care. Finally, we highlight the importance of collaborations in adrenal tumor research, which allowed for these recent advances and provide structures for future success in this scientific field.
\end{abstract}

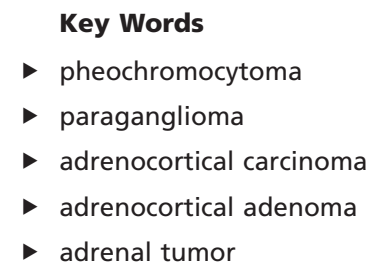

Endocrine-Related Cancer (2018) 25, R405-R420

\section{Introduction}

Clinically unapparent adrenal tumors are found in $2-10 \%$ of the population worldwide. Cases that do require treatment are enriched in risk populations particularly those with hypertension or genetic risk factors (overview in Fassnacht et al. 2016, Young et al. 2017). Those that are associated with endocrine disturbances can cause severe patient morbidity and remains difficult to recognize and diagnose. Metastatic disease is a rare but lethal condition that can only be cured through complete surgical resection. Thus, in order to improve outcomes from adrenal tumor disease, there is a clear need for improved diagnostic methods, prognostic and predictive biomarkers but most importantly for improved therapeutic strategies.

Here, we performed a systematic review of research papers with an electronic publication date during 2017 and that were focused on adrenal tumors. A total of 349 papers including basic science and clinical studies were identified - 154 on pheochromocytomas (PCCs) and paragangliomas (PGLs, collectively denoted PPGLs), 177 on adrenocortical tumors and 18 that fell into a general adrenal tumor category. In this review, we have referenced 110 of these manuscripts and selected three prominent topics that we felt deserved special attention (Table 1). We also identified 21 active interventional studies on clinicaltrials.gov, 13 for PPGLs and 10 for adrenocortical tumors (Tables 2 and 3). Key drivers behind this research included researchers that were affiliated to the United States National Institutes of Health $(\mathrm{NIH})$, European Network for the Study of Adrenal Tumors (ENSAT) or the newly formed American-Australian-Asian Adrenal Alliance (A5). In numbers, they were involved in 37\% of the research papers assessed in our survey, with the number increasing to 50,62 , and $82 \%$ if considering papers with impact factor $\geq 3, \geq 6$, and $\geq 9$, respectively. Two placebo-controlled clinical trials for adrenal tumors (FIRSTMAPP and ADIUVO) were both initiated and 
Table 1 Selected topics and studies during 2017.

Topic
PPGL, molecular characterization and data
repository
ACC, translating molecular characteristics
into robust prognostic markers

APA, candidates for drug repositioning

Title
Comprehensive molecular characterization of
pheochromocytoma and paraganglioma
DNA methylation is an independent prognostic marker of
survival in adrenocortical cancer
Assessment of VAV2 expression refines prognostic prediction in
adrenocortical carcinoma
Macrolides blunt aldosterone biosynthesis: a proof-of-concept
study in KCNJ5 mutated adenoma cells ex vivo
Macrolides selectively inhibit mutant KCNJ5 potassium channels
that cause aldosterone-producing adenoma

Reference

Fishbein et al. (2017b)

Jouinot et al. (2017)

Sbiera et al. (2017)

Caroccia et al. (2017)

Scholl et al. (2017) that cause aldosterone-producing adenoma

ACC, adrenocortical carcinoma; APA, aldosterone-producing adenoma; PPGL, pheochromocytoma and paraganglioma

executed through members of ENSAT. NIH and A5 were both associated with six clinical trials each. Guidelines relevant to adrenal tumor patients are summarized in Table 4.

\section{Development and molecular characterization of the adrenal gland}

Del Valle et al. studied adrenogonadal development during weeks 6-10 and characterized the processes of testis determination, onset of steroidogenesis and primordial germ cell development. Their genomic atlas of human adrenal and gonad development proposed new candidate genes for adrenal and reproductive disorders (Del Valle et al. 2017). The adrenal medulla is thought to originate from cells of the neural crest. Furlan et al. provided further evidence that multipotent peripheral glial cells also generate neuroendocrine cells of the adrenal medulla (Furlan et al. 2017).
The Human Protein Atlas (https://www.proteinatlas. org) aims to map all the human proteins in cells, tissues and organs using integration of various omics technologies. It has employed more than 26,000 antibodies on multiple tissues, cells and pathological states. The consortium now presented their data on the adrenal gland with RNA sequencing of tissue homogenates that identified 253 genes with an elevated expression pattern compared to other tissues (Bergman et al. 2017). Spatial expression patterns of the translated proteins were studied using immunohistochemistry.

\section{Incidentally discovered adrenal tumors}

Clinical practice guidelines issued by the European Society of Endocrinology and ENSAT provide 19 recommendations, 16 of which are based on very lowquality evidence and 3 on low-quality evidence. The recommendations assert that adrenal tumors $<4 \mathrm{~cm}$

Table 2 Recruiting clinical trials for PPGL.

\begin{tabular}{l} 
Intervention \\
\hline Randomized studies \\
Sunitinib \\
Phenoxybenzamine vs doxazosin \\
Phenoxybenzamine vs doxazosin \\
Non-randomized studies \\
Cabozantinib \\
SGI-110 (Guadecitabine) \\
Lenvatinib \\
Lu-177-DOTATATE \\
Studies investigating multiple disease \\
131I-MIBG \\
131I-MIBG \\
Nivolumab and ipilimumab \\
ONC-201 \\
Pembrolizumab \\
PEN-221
\end{tabular}

Study design
Phase II, placebo controlled
Phase III
Phase IV
Phase II, single arm
Phase II, single arm
Phase II, single arm
Phase II, single arm
Phase II, single arm
Phase II, single arm
Phase II, single arm
Phase II, single arm
Phase II, single arm
Phase I/Ila, single arm

\begin{tabular}{l} 
Setting \\
\hline Palliative \\
Curative and palliative \\
Curative \\
Palliative \\
Palliative \\
Palliative \\
Palliative \\
Palliative \\
Palliative \\
Palliative \\
Palliative \\
Palliative \\
Palliative
\end{tabular}

\section{Recruitment} target, $n$ patients

$\begin{array}{r}74 \\ 60 \\ 134 \\ 22 \\ 70 \\ 25 \\ 90 \\ 80 \\ 100 \\ 707 \\ 24 \\ 250 \\ 120 \\ \hline\end{array}$

NCT number

NCT01371201

NCT03176693

NCT01379898

NCT02302833

NCT03165721

NCT03008369

NCT03206060

NCT00107289

NCT01850888

NCT02834013

NCT03034200

NCT02721732

NCT02936323

NCT, ClinicalTrials.gov registry number; PPGL, pheochromocytoma and paraganglioma.

http://erc.endocrinology-journals.org https://doi.org/10.1530/ERC-18-0138 (c) 2018 The authors Published by Bioscientifica Ltd. Printed in Great Britain
This work is licensed under a Creative Commons Attribution 4.0 International License. 
Table 3 Recruiting clinical trials for adrenal cortical tumors.

\begin{tabular}{|c|c|c|c|c|}
\hline Intervention & Design & Setting & $\begin{array}{l}\text { Recruitment } \\
\text { target, } n \text { patients }\end{array}$ & NCT number \\
\hline \multicolumn{5}{|l|}{ Randomized } \\
\hline Mitotane & Phase III & Adjuvant & 200 & NCT00777244 \\
\hline ATR-101 & Phase II, placebo controlled & $\begin{array}{l}\text { Palliative (symptom } \\
\text { reduction) }\end{array}$ & 16 & NCT03053271 \\
\hline $\begin{array}{l}\text { Surgery + medical therapy vs medical } \\
\text { therapy }\end{array}$ & Randomized study & Curative & 110 & NCT02364089 \\
\hline \multicolumn{5}{|l|}{ Non-randomized } \\
\hline RF-ablation & Single-arm study & Curative & 25 & NCT02756754 \\
\hline Pembrolizumab & Phase II, single arm & Palliative & 39 & NCT02673333 \\
\hline \multicolumn{5}{|l|}{ Studies investigating multiple diseases } \\
\hline ABBV-176 & Phase I, single arm, basket & Palliative & 100 & NCT03145909 \\
\hline Cabozantinib-S-malate & Phase II, single arm & Palliative & 110 & NCT02867592 \\
\hline Nivolumab and ipilimumab & Phase II, single arm & Palliative & 57 & NCT03333616 \\
\hline Nivolumab and ipilimumab & Phase II, single arm & Palliative & 707 & NCT02834013 \\
\hline Pembrolizumab & Phase II, single arm & Palliative & 250 & NCT02721732 \\
\hline
\end{tabular}

NCT, ClinicalTrials.gov registry number; RF, Radiofrequency.

with imaging characteristics of $\leq 10$ Hounsfield units do not require further follow-up imaging. Recently, these data were now confirmed by a retrospective follow-up study (Hong et al. 2017). Conflicting data state that, for such patients, one-time follow-up evaluation involving a noncontrast CT and biochemical evaluation is costeffective (Chomsky-Higgins et al. 2018).

For intermediate lesions, there is an increasing amount of data that ${ }^{18} \mathrm{~F}$-fluorodeoxyglucose (FDG) PET/CT could improve diagnosis (Altinmakas et al. 2017, Delivanis et al. 2018). A prospective study showed that ${ }^{18} \mathrm{~F}-\mathrm{FDG}$ PET/CT complements adrenal washout CT in the evaluation of adrenal masses with $86.7 \%$ sensitivity and $86.1 \%$ specificity for the detection of adrenocortical carcinoma (ACC) (Guerin et al. 2017). Finally, computational analysis of images data represents another venue to improve classification of adrenal tumors;
Chai et al. performed a retrospective experiment where they reached a $90 \%$ accuracy analyzing 436 CT scans (Chai et al. 2017). Although prospective studies are lacking, we expect this field to evolve fast.

\section{PCC and PGL}

Our synthesis of the advances in PPGL is provided in Fig. 1.

\section{Clinical studies}

\section{Classifications}

The World Health Organization has released updated classifications of tumors from endocrine organs as well as the head and neck region. PPGLs are now

Table 4 Guidelines on adrenal tumors.

\begin{tabular}{l}
\hline Topic \\
\hline Published during 2017 \\
Adrenal incidentalomas, diagnosis \\
PPGL, surveillance recommendations \\
PPGL, genetic diagnosis and NGS \\
ACC, surgery \\
Published earlier than 2017 \\
Adrenal incidentalomas, diagnosis \\
PPGL, management \\
PPGL, follow-up \\
Primary aldosteronism, management \\
Cushing syndrome, diagnosis \\
Cushing syndrome, treatment
\end{tabular}

\begin{tabular}{l}
\hline Year \\
\hline 2017 \\
2017 \\
2017 \\
2017 \\
2016 \\
2014 \\
2016 \\
2016 \\
2008 \\
2015
\end{tabular}

Organization
ACR
Consensus Committee
Consensus Committee
ESES \& ENSAT
ENSAT
Endocrine Society
ESE
Endocrine Society
Endocrine Society
Endocrine Society

Reference

Mayo-Smith et al. (2017)

Rednam et al. (2017)

Toledo et al. (2017)

Gaujoux \& Mihai (2017)

Fassnacht et al. (2016)

Lenders et al. (2014)

Plouin et al. (2016)

Funder et al. (2016)

Nieman et al. (2008)

Nieman et al. (2015)

ACC, adrenocortical carcinoma; ACR, American College of Radiology; ENSAT, European Network for the Study of Adrenal Tumors; ESE, European Society of Endocrinology; ESES, European Society of Endocrine Surgeons; NGS, next-generation sequencing; PPGL, pheochromocytoma and paraganglioma. 
Advances in PPGL in 2018

\begin{tabular}{|c|c|c|}
\hline \multicolumn{3}{|c|}{ Advances in PPGL in 2018} \\
\hline $\begin{array}{l}154 \\
\text { published } \\
\text { research } \\
\text { papers }\end{array}$ & $\begin{array}{l}13 \\
\text { interventional } \\
\text { clinical trials } \\
\text { recruiting }\end{array}$ & $\begin{array}{c}173 \\
\text { tumors with } \\
\text { pan-molecular } \\
\text { data (TCGA) }\end{array}$ \\
\hline \multicolumn{3}{|c|}{ Improved classification and prognostication } \\
\hline $\begin{array}{l}2017 \text { WHO } \\
\text { classification }\end{array}$ & $\begin{array}{c}2017 \text { AJCC } \\
\text { staging system }\end{array}$ & $\begin{array}{l}\text { TCGA Molecular } \\
\text { subgroups }\end{array}$ \\
\hline \multicolumn{3}{|c|}{ Translating molecular findings into clinical care } \\
\hline $\begin{array}{c}\text { Surveillance } \\
\text { of gene } \\
\text { carriers }\end{array}$ & $\begin{array}{l}\text { Predictive factors } \\
\text { for medical and } \\
\text { surgical treatment }\end{array}$ & $\begin{array}{l}\text { Unique functional } \\
\text { imaging signatures }\end{array}$ \\
\hline \multicolumn{3}{|c|}{ Collaborations gain momentum } \\
\hline$\overbrace{\text { ens@t }}^{\text {and }}$ & $\begin{array}{l}\text { Founded in } 2002 \\
100 \text { institutions } \\
31 \text { countries }\end{array}$ & $\begin{array}{c}\text { Founded in } 2015 \\
13 \text { institutions } \\
4 \text { countries }\end{array}$ \\
\hline
\end{tabular}

Figure 1

Advances in PPGL in 2018. A5, American-Australian-Asian Adrenal Alliance; AJCC, American Joint Committee on Cancer; ENSAT, European Network for the Study of Adrenal Tumors; PPGL, pheochromocytoma and paraganglioma; TCGA, The Cancer Genome Atlas; WHO, World Health Organization.

classified as PCCs, sympathetic PGLs or head and neck (parasympathetic) PGLs (Lam 2017, Lloyd et al. 2017, Williams \& Tischler 2017). Both classifications highlight the hereditary nature of PPGLs and emphasize that they 'remain tumors of undetermined biologic potential and should not be termed benign'. This classification has been complemented by the first TNM staging system for PPGL released by the American Joint Committee on Cancer (Jimenez et al. 2017, Roman-Gonzalez \& Jimenez 2017).

\section{Disease outcomes}

\section{Outcome from catecholamine excess}

A study using the Nationwide Inpatient Sample studied outcomes after unilateral adrenalectomy among patient with hormonally active tumors $(n=6033)$, those with PCCs had a higher rate of comorbidities including congestive heart failure, chronic lung disease and malignant hypertension (Parikh et al. 2017). A systematic review identified 163 occurrences of PCCs and cardiomyopathy (Zhang et al. 2017). Hypertension was the presenting symptom in $65 \%$ and the classic triad of headache, palpitations and diaphoresis was observed in only $4 \%$.
PCC resection led to improvement of cardiomyopathy in $96 \%$ of patients, while lack of resection was associated with death or cardiac transplantation in $44 \%$ patients. Majtan et al. performed a prospective study on the effects of surgical resection on carotid intima-media thickness and left ventricular mass in 50 PPGL patients (Majtan et al. 2017). Both parameters significantly regressed after tumor removal; in contrast to patients with essential hypertension.

\section{Outcome from metastatic disease}

A meta-analysis on outcomes of patients with metastatic PPGLs showed a 5-year survival rate of 63\% (95\% CI, $49-76 \%$ ) with poor survival associated with male sex and synchronous metastases (Hamidi et al. 2017a). The authors also describe the natural course of metastatic PPGLs at their referral center (Hamidi et al. 2017b). Among 272 patients, the median overall survival was 24.6 years. On the other hand, a subset of patients had a very aggressive disease course of the disease. This remarkably variability in patients affected by metastatic PPGL is supported by the authors' own experience.

\section{Prospective clinical trials}

\section{High-specific activity I-131 meta-iodobenzylguanidine}

In a phase 1 study, safety and efficacy of this compound was investigated in 21 metastatic PPGLs (Noto et al. 2018). The maximum tolerated dose was determined and the majority (84\%) of adverse events were considered mild or moderate in severity. A $19 \%$ response rate on anatomical imaging was reported, only patients who received $>18.5 \mathrm{GBq}$ of study drug had a response.

\section{Pazopanib}

This phase II trial for advanced/progressive metastatic PPGL was halted due to poor accrual (Jasim et al. 2017). One of six patients had a partial response (duration 2.4 years). The authors stress that optimal alpha- and beta-adrenoceptor blockade is important in patients with secretory tumors to avoid risk of potentially lifethreatening complications.

\section{Retrospective studies}

\section{Surgical treatment}

In 53 PPGLs with synchronous metastases, patients with surgical resection of the primary tumor have a longer

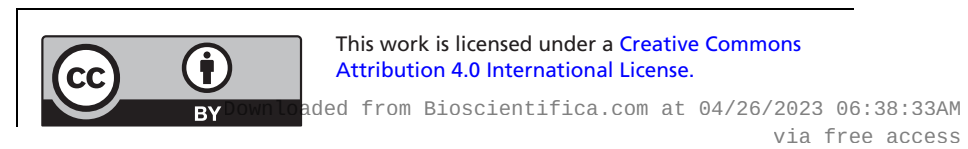


overall survival than those who did not (85 months vs 36 months) (Roman-Gonzalez et al. 2017). A second study investigated perioperative complications in 110 patients with and 166 without alpha-adrenoceptor blockade (Groeben et al. 2017). There was no difference in the incidence of excessive hypertensive episodes between the groups and no major complications occurred. The authors concluded that 'the basis for the general recommendation of perioperative $\alpha$-receptor blockade for PCC surgery demands further study'. A commentary stated that 'when considering abandoning this conventional therapy altogether, one needs to carefully consider the confidence regarding the safety of this revised approach' (Grocott 2017). In addition, this study does not consider preoperative safety that is of concern in patients with catecholamine-secreting tumors.

\section{Oncological treatment}

Efficacy and safety of peptide receptor radionuclide therapy (PRRT) (Kong et al. 2017), in combination with 131I-meta-iodobenzylguanidine (MIBG) (Nastos et al. 2017), interferon-alpha (Hadoux et al. 2017), and cyclophosphamide, vincristine and dacarbazine (CVD) were reported from retrospective materials. $S D H B$ patients had a higher response rate to CVD compared to those without SDHB mutations (Asai et al. 2017, Fishbein et al. 2017a).

\section{Translating molecular findings to the clinic}

Disease penetrance and surveillance of gene carriers

Mutations in succinate dehydrogenase subunits A-D (SDHx) were thought to have almost complete penetrance for PPGL. This figure has now been adjusted, a finding of major importance when designing surveillance protocols for healthy carriers: the overall penetrance of $S D H B$ mutations was estimated to be $21 \%$ at the age of 50 years and $42 \%$ at the age of 70 years (Rijken et al. 2018). A second study showed a penetrance of $49.8 \%$ at 85 years (Jochmanova et al. 2017). Penetrance of any SDHArelated manifestation in non-index patients was $13 \%$ at age 40 years (Bausch et al. 2017) and 10\% at the age of 70 years (van der Tuin et al. 2018). The clinical spectrum associated with hereditary leiomyomatosis and renal cell carcinoma syndrome (associated with $\mathrm{FH}$ mutations) was assessed in 182 cases from 114 families and found only two cases of PPGL (Muller et al. 2017).

These findings align with a calculation of the optimal surveillance for head and neck PGL in SDHB mutation carriers; it has been suggested to start at the age of 27 with an interval of 3.2 years (Eijkelenkamp et al. 2017). The second study reported outcomes of annual surveillance imaging in SDHB mutation carriers (Tufton et al. 2017): in 27 index patients, 51 PPGLs (five metachronous) were detected. SDHB-related tumors occurred in $25 \%$ of asymptomatic carriers on surveillance screening: ten on the first surveillance imaging and five on subsequent imaging 2-6 years later. The authors suggested the use of annual or biannual imaging with MRI. These intervals are in line with recommendations on surveillance in childhood for some hereditary PPGLs (Rednam et al. 2017).

\section{Evaluation and treatment}

\section{Functional imaging}

It is now established that the most optimal tracer for PET imaging can be selected from an underlying driver mutation. This knowledge was further refined in patients with polycythemia/PGL syndrome, optimal tracers being ${ }^{18} \mathrm{~F}$-dihydroxyphenylalanine and ${ }^{18} \mathrm{~F}$-fluorodopamine as well as pediatric $S D H x$-associated PPGL, optimal tracer being ${ }^{68} \mathrm{Ga}$-tetraazacyclododecane tetraacetic acid-octreotate (DOTATATE) (Janssen et al. 2017, Jha et al. 2017). Previous results also showed superiority of ${ }^{68} \mathrm{Ga}$-DOTATATE for detection of SDHB-related metastatic PPGL as well as PGLs of the head and neck (Janssen et al. 2015, Janssen et al. 2016). We believe that these findings will lead to a change in golden standard for staging and localization of PPGL from 18F-FDG-PET to a precision medicine-based approach. The norepinephrine transporter has a long-standing tradition as a target for ${ }^{123}$ I-MIBG scintigraphy, that has inborn limitations related to the imaging technology. Pandit-Taskar et al. described a PET analog, ${ }^{18}$ F-meta-fluorobenzylguanidine, that was safe, had favorable biodistribution and with good targeting of tumors (Pandit-Taskar et al. 2018).

\section{Surgery}

Preoperative genetic testing of PPGLs was found to influence the surgical approach and the extent of adrenal surgery (Nockel et al. 2018). Those with RET, VHL or NF1 germline mutations more often had minimally invasive surgery with cortical-sparing adrenalectomy, whereas seven out of eight (87.5\%) patients with SDHB mutation had an open approach. The underlying argument was to preserve cortical function in patients with a high risk of bilateral PCC having a low risk of metastatic disease 
(RET and VHL carriers), whereas those with a low risk of bilateral PPC but with risk factors for metastases (including $S D H B$ and large tumor size) could benefit from an open approach to maximize probability of radical resection. A second study show that patients with NF type 1 had more volatile intraoperative course and more severe complications, probably related to larger tumors and abundant catecholamine secretion that resulted in a high proportion of open resections (Butz et al. 2017).

\section{Pathology}

Koh et al. evaluated grading systems for predicting metastatic potential in PPGLs: they validated the grading system for PPGL (GAPP) and proposed a modified GAPP with addition of $S D H B$ staining to be useful for the prediction of the metastatic potential and prognosis in PPGL (Koh et al. 2017).

\section{Translational research and basic science}

\section{Molecular atlas of PPGL: the Cancer Genome Atlas study}

The Cancer Genome Atlas described results from 173 PPGLs that were analyzed with six different molecular profiling technologies, the most comprehensive molecular characterization of PPGL ever performed (Fishbein et al. 2017b). All data are freely available online (https://gdc. cancer.gov) and serves to accelerate research in this rare entity. Disease-causing mutations or gene fusions occurred in $73 \%$ of cases. At least two novel disease-causing genes were identified: MAML3 and CSDE1. Integrated analysis classified PPGL into three main subtypes: kinase signaling, pseudohypoxia and Wnt altered. A forth subtype, cortical admixture, was also detected but is thought to reflect a signal from non-tumoral cells.

Data from The Cancer Genome Atlas (TCGA) have already allowed PPGL to be included into several pancancer analyses; the first underscore that PPGL genomes exhibit relatively low number of somatic mutations as well as copy number segmentations compared to other tumors (Cancer Genome Atlas Network 2017). The second study investigated patterns of selection in cancer and confirmed known PPGL drivers as subjected to positive selection (Martincorena et al. 2017). Smaller studies complement the TCGA effort by demonstrating activating FGFR1 mutations (Welander et al. 2018) as well as different landscapes of aneuploidy in $S D H B$ versus $S D H A F 2, S D H D$ and VHL-related cases (Hoekstra et al. 2017). One aspect that TCGA did not cover was tumor evolution. Flynn et al. reported data from sequencing of tumors from syndromic patients with multiple PPGLs, different tumors shared rare somatic copy number suggesting that these changes could have been acquired early within common precursor cells (Flynn et al. 2017).

A third pan-cancer study performed a systematic analysis of telomere length, PPGLs were found to be exceptional as it lacks both telomerase reverse transcriptase (TERT) expression and mechanisms of alternative lengthening of telomeres in the highest proportion of cases (Barthel et al. 2017). Two mechanisms underlying increased TERT expression were identified: TERT structural rearrangements (Dwight et al. 2018) and TERT promoter hypermethylation (Svahn et al. 2018). These molecular data have allowed the stratification of PPGLs into subgroups have distinct molecular-biochemical-imaging signatures (reviewed in Crona et al. 2017).

\section{New treatment candidates and tumor models}

Lack of representative tumor models has impeded progress toward new therapeutics for PPGLs. This year, patient-derived xenografts in NOD SCID gamma mice (Powers et al. 2017) as well as SDHB-silenced mouse PCC spheroids (D'Antongiovanni et al. 2017) were described and could potentially fill this gap. Effect of the following agents was suggested: HSP90 inhibitor (NVP-AUY922) in PC12 cells (Lian et al. 2017), anthracyclines through inhibition of the hypoxia signaling pathway in mouse PCC cell lines (Pang et al. 2017) and proteasome inhibitor (Bortezomib) in mouse PCC cell lines (Bullova et al. 2017). Rapalogues is approved for treatment for gastrointestinal neuroendocrine tumors but its efficacy in PPGLs has been doubted. This may have to be re-challenged as the mTORC1 complex was found to be overactivated in PPGL both of the head and neck and those harboring SDHx mutations (Oudijk et al. 2017).

\section{Adrenocortical tumors}

Our synthesis of the advances in adrenocortical tumors is provided in Fig. 2.

\section{Improved diagnosis}

The 2017 World Health Organization classification recognizes Weiss score as the primary determinant of malignancy of adrenocortical tumors (Lam 2017, Lloyd et al. 2017). Three rare subtypes of ACC are recognized - oncocytic, myxoid and sarcomatoid 
carcinomas. Clinical and biochemical features together with absence of malignant criteria are used to diagnose adrenocortical adenoma (ACA). Thus, improved methods for subclassification of adrenocortical tumors are sought for: in three independent studies, the authors showed that different adrenal disorders have unique metabolic fingerprints that can be detected in serum or urine through mass spectrometry (Hines et al. 2017, Patel et al. 2017, Taylor et al. 2017). The aldosterone-to-renin ratio was evaluated prospectively for detection of aldosterone-producing adenoma (APA); baseline and post-captopril aldosterone-renin ratio showed similar diagnostic accuracy in both the exploratory and validation cohorts, indicating lack of diagnostic gain with this confirmatory test (Maiolino et al. 2017). Radiographically identified adrenal nodules are not always a source of primary aldosteronism (PA), even when ipsilateral lateralization on adrenal vein sampling occurs (Nanba et al. 2017). One alternative could be targeting CXC chemokine receptor type 4 for functional imaging classification of both APA (Heinze et al. 2018) and ACC (Wu et al. 2017).

\section{Advances in adrenocortical tumors 2018}

177

published research papers
10

interventional clinical trials recruiting
91

Tumors from TCGA 6 omics platforms public repository
Improved classification and prognostication

$\begin{array}{llc}2017 \text { WHO } & \begin{array}{c}\text { Current ENSAT } \\ \text { staging system }\end{array} & \text { TCGA Molecular } \\ \text { subsification } & \text { subroups }\end{array}$

Translating molecular findings into clinical care

Prognostic Treatment targets Unique functional

Collaborations gain momentum

ens@t $\begin{gathered}\text { Founded in } 2002 \\ 100 \text { institutions } \\ 31 \text { countries }\end{gathered} \underbrace{5}_{\begin{array}{c}\text { Founded in } 2015 \\ 13 \text { institutions } \\ 4 \text { countries }\end{array}}$

Figure 2

Advances in adrenocortical tumors in 2018. A5, American-AustralianAsian Adrenal Alliance; ENSAT, European Network for the Study of Adrenal Tumors; TCGA, The Cancer Genome Atlas; WHO, World Health Organization

\section{Adrenocortical adenoma}

\section{Outcomes}

A prospective study determined the prevalence of PA among 1672 primary care patients with hypertension: 5.9\% had PA and one-third of these had a unilateral APA accordingly to adrenal CT scanning and adrenal vein sampling (Monticone et al. 2017). A meta-analysis of 3838 patients with PA revealed an increased risk of stroke (OR 2.58, 95\% CI 1.93-3.45), coronary artery disease $(1.77,1.10-2.83)$, atrial fibrillation $(3.52,2.06-5.99)$ and heart failure $(2.05,1.11-3.78)$ compared to patients with essential hypertension (Monticone et al. 2018). Patients with PA were also shown to have deteriorated bone quality without loss of overall bone mass (Kim et al. 2018).

Data from the randomized SPARTACUS trial was used to study quality of life in PA patients: 1 year post adrenalectomy, quality of life normalized, whereas for patients on medical treatment, quality of life had improved but was inferior to the level of the general population (Velema et al. 2018).

\section{Cortisol secretion: utility in multiple scenarios}

Arlt et al. analyzed steroid metabolome in 174 newly diagnosed patients with PA (103 APA, 71 bilateral adrenal hyperplasia) (Arlt et al. 2017). Patients with PA had significantly increased cortisol and total glucocorticoid metabolite excretion, only exceeded by glucocorticoid output in patients with clinically overt adrenal Cushing syndrome. In a second series, 4/5 APAs with concurrent subclinical cortisol hypersecretion were found to be composed of zona fasciculata-like cells, with heterogenous CYP11B1 and CYP11B2 immunostaining and lacking driver mutations associated with APA (Fallo et al. 2017).

Two studies confirmed the association between nonfunctional ACA with autonomous cortisol secretion to cardiovascular disease (Arruda et al. 2017) as well as increased mortality (Patrova et al. 2017). This was corroborated in a third study that suggested increased visceral fat as an explanation (Yener et al. 2017).

Finally, perioperative ACTH, steroid precursors and tumor size was found to predict recurrence of Cushing's disease (El Asmar et al. 2018).

\section{Translating molecular findings to the clinic: new treatment options}

Molecular characterization of APA has pinpointed key disease driving mechanisms that are now exploited 
by researchers as biomarkers and therapeutic targets (reviewed in Zennaro et al. 2017).

\section{Surgical therapy}

Kitamoto et al. correlated outcome to somatic mutation status among 142 patients with APA; KCNJ5 mutations in young patients with APA emerged as a prognostic biomarker indicating resolution of hypertension (Kitamoto et al. 2018). A second study found that CTNNB1-mutated APA had a higher possibility of residual hypertension (Wu et al. 2017).

\section{Medical therapy}

Following the discovery of somatic mutations in KCNJ5 (potassium channel) as a driver of APA, macrolides were shown to selectively inhibit mutant KCNJ5 opening, which might provide the option for improved diagnosis and treatment (Caroccia et al. 2017, Scholl et al. 2017). Other potential therapeutic targets of PA included the E3 ubiquitin ligase Siah1 (Scortegagna et al. 2017), neurofilament medium polypeptide (Maniero et al. 2017) and calneuron 1 (Kobuke et al. 2018).

\section{Translational research and basic science}

\section{APA}

Biology and clinicopathological characteristics of this disorder are dependent on the mutational status, an expanding field that came up with several clarifying publications (Murakami et al. 2017, Tan et al. 2017). However, whether PA is the consequence of a monoclonal or multiclonal processes is still not clear. Aging was found to correlate with remodeling of the adrenal cortex and emergence of subcapsular aldosterone-producing cell clusters (APCCs) that replaced the continuous zona glomerulosa layer. In a first study, the authors provided evidence that PA involves polyclonal APAs (Omata et al. 2017b). A second study studied 107 unilateral adrenal glands obtained from autopsies of nonhypertensive patients. Sixty-one APCCs were detected (average of 0.6 APCCs per gland) (Omata et al. 2017a). In a third study of PA patients with negative cross-sectional imaging, the resected adrenal gland showed that 13 had multiple adrenocortical micronodules and 12 had diffuse hyperplasia of zona glomerulosa based upon histopathological evaluation and CYP11B2 IHC. Aldosterone-driver gene somatic mutations were detected in 21 of $26(81 \%)$ of
CYP11B2-positive cortical micronodules (Yamazaki et al. 2017). Finally, a study reported six patients with possible APCC-to-APA transitional lesions (Nishimoto et al. 2017). These data questions if the current classification that recognizes either unilateral APA or bilateral hyperplasia is relevant especially as future personalized treatment options might be based on molecular findings rather than tumor size.

\section{Cortisol-producing adenoma}

Protein kinase A catalytic alpha subunit is a disease driver in $30-40 \%$ of cortisol-producing adenoma (CPA) and was associated with reduced DNA methylation at the CYP11B1 promoter that may result in CYP11B1 transcription and hypercortisolemia (Kometani et al. 2017). A second study characterized expression of the protein kinase A subunits in normal adrenal glands and ACA (Weigand et al. 2017). The molecular etiology behind a rare subtype of Cushing syndrome caused by ectopic expression of glucosedependent insulinotropic polypeptide receptor (GIPR) was unveiled; microduplications at chromosome 19q13 that contain the GIPR locus (Lecoq et al. 2017).

\section{Adrenocortical carcinoma}

\section{Outcome and prognostic factors}

Partial response (PR) has been proposed as a surrogate for overall survival in ACC. This study found that most patients with metastatic ACC and long survival times had PR within the first 6 months of systemic therapy, and almost all within the first year. The absence of response after that period could be considered as a treatment failure (Vezzosi et al. 2018). Eighty-two patients with high-risk pediatric ACC were evaluated for outcome and prognostic factors: distant metastases and large tumor volume were associated with unfavorable prognosis (Cecchetto et al. 2017).

\section{Improved classification and prognosis}

It is clear that the most optimal clinicopathological classification of ACC has yet to be determined. The United States ACC Study Group analyzed 149 patients and proposed a refined TNM classification with a novel T-Stage (Poorman et al. 2018). In a second study, the Helsinki Score, a diagnostic and prognostic system based on the combined evaluation of mitoses and necrosis as well as Ki-67 index, was investigated in 225 cases of 
ACC (Duregon et al. 2017). The third study found that low mitotic tumor grade, Weiss score, global loss of DAXX expression and high phospho-mTOR expression correlated with disease-free survival (Mete et al. 2018).

\section{Clinical studies}

\section{Prospective clinical trial}

A Phase 1 study of ARQ 087, an oral pan-FGFR inhibitor, was investigated in patients with advanced solid tumors (Papadopoulos et al. 2017). This was a basket trial that included one patient with a FGFR1-amplified ACC that showed stabled disease upon treatment.

\section{Retrospective studies, surgical treatment}

Outcome after resection of ACC liver metastases was studied in 77 patients without extrahepatic disease (Baur et al. 2017). The median overall survival was 76.1 months in 43 patients that underwent metastasectomy, compared to 10.1 months in the 34 patients without surgical resection. However, the median disease-free survival in resected ACC was only 9.1 months. A second study investigated perioperative blood transfusion that has been associated with decreased survival in pancreatic, gastric and liver cancer. Perioperative transfusion was associated with earlier recurrence and decreased survival after curative-intent resection of ACC (Poorman et al. 2017). Another study proposed a threshold for surgeon volume to minimize complications and decrease cost associated with adrenalectomy (Anderson et al. 2018). A total of 3496 surgeons performed adrenalectomies on 6712 patients; median annual surgeon volume was 1 case. After adjustment, the likelihood of experiencing a complication decreased with increasing annual surgeon volume up to 5.6 cases (95\% CI, 3.27-5.96). Recommendations for the perioperative surgical care of patients with ACC from the European Society of Endocrine Surgeons and ENSAT are now available (Gaujoux \& Mihai 2017).

\section{Oncological treatment}

One hundred forty-five ACC received gemcitabine based chemotherapy, PR or stable disease was achieved in 4.9 and 25.0\%, respectively (Henning et al. 2017). No predictive factors could be identified. Claps et al. reported that the combination of metyrapone with mitotane, etoposide, doxorubicin and cisplatinin (EDP-M) achieved rapid control of Cushing syndrome induced by cortisolsecreting ACC in three patients (Claps et al. 2017). ERCC1, involved in DNA excision repair, was investigated as a predictive biomarker of platinum-based chemotherapy in 146 ACC but demonstrated negative results (Laufs et al. 2018). A second predictive marker topoisomerase II alpha, showed a positive correlation to EDP-M, disease response or stabilization was observed in 21/30 topoisomerase II alpha positive ACC compared to 5/22 in those without the biomarker (Roca et al. 2017).

\section{Translating molecular findings to the clinic}

Comprehensive characterization of ACC biology was previously achieved by TCGA and ENSAT consortiums that together proposed a robust molecular classification (Assie et al. 2014, Zheng et al. 2016). Prognostic impacts of these subgroups were analyzed using methodologies compatible with clinical diagnostic use. Jouinot et al. investigated DNA methylation and Sbiera et al. investigated VAV2 gene expression (Jouinot et al. 2017, Sbiera et al. 2017). Both methods revealed a strong correlation to survival that was independent to traditional measures in their multivariate analyses. These studies will pave the way of including new prognostic biomarkers into the traditional classification of ACC.

A study of 60 pediatric ACCs investigated the impact of germline TP53 mutations and showed similar prognosis and outcome regardless of mutation status. Ki67 index was a promising prognostic biomarker also in pediatric ACC (Pinto et al. 2017).

\section{Liquid biopsy}

Independent studies show that circulating tumor DNA can be found in a subset of ACC with high tumor burden (Creemers et al. 2017, Garinet et al. 2018). These early data implies that liquid biopsy has the potential to be used to estimate relative changes in tumor volume as well as to determine the genetic composition of a subset of ACC. Traces of extracellular vesicle-associated microRNAs in the blood was also found to be useful but for a different purpose; perioperative diagnosis of ACC (Perge et al. 2017).

\section{Translational research and basic science}

\section{New genetic risk factors}

Five out of 21 patients with $M U T Y H$-associated polyposis had adrenal lesions; two were hyperfunctioning. Among four patients that underwent adrenalectomy, three had benign tumors and one was oncocytic of uncertain malignant potential (Kallenberg et al. 2017). Traces of 
MUTYH deficiency can be found in tumor mutatomes through a unique signature of DNA mutations. Pilati et al. were able to detect this MUTYH deficiency signature in ACC (Pilati et al. 2017). Finally, succinate dehydrogenase gene mutations were found in four unrelated patients with cortisol-secreting ACC (Else et al. 2017). A majority lacked molecular hallmarks associated to $S D H x$ deficiency.

\section{ACC pathogenesis}

The TCGA dataset has now allowed researchers not involved in the adrenal field to characterize ACC and compare it to other cancers. Three different studies compared the mutational landscape (Cancer Genome Atlas Network 2017), patterns of selection (disease evolution) (Martincorena et al. 2017) as well as telomere length and somatic alterations (Barthel et al. 2017).

\section{New treatment candidates and tumor models}

\section{CDK4-6 inhibitors}

CDK4 and CDK6 inhibitors were suggested to be candidate drugs for treatments of ACC (Hadjadj et al. 2017) and a second study identified palbociclib to inhibit proliferation of human adrenocortical tumor cells (Fiorentini et al. 2018).

\section{Aurora kinase inhibitors}

The aurora kinase inhibitor AMG 900 increased apoptosis and chemosensitivity to anticancer drugs in the NCI-ACC cell line (Borges et al. 2017).

\section{Guanine nucleotide exchange factor VAV2}

VAV2 was mentioned earlier as a prognostic factor, this study revealed molecular mechanisms involved and suggest that blocking VAV2 may be a new therapeutic approach to inhibit metastatic progression (Ruggiero et al. 2017).

\section{Rotterin}

Rottlerin was introduced as a novel chemotherapy agent (Zhu et al. 2017) and synthetic high-density lipoprotein nanodisks for targeted delivery to ACC (Kuai et al. 2017).

\section{mTOR and SSTR2 pathways}

Analyses of the mTOR and SSTR2 pathways in ACC cell lines H295R and SW13 (Germano et al. 2017) revealed that everolimus monotherapy and combinations with either mitotane or pasireotide resulted in growth inhibition.

\section{Acyl-CoA acyltransferase 1 inhibition}

ATR-101 was found to inhibit cholesterol efflux and cortisol secretion by ATP-binding cassette transporters, causing cytotoxic cholesterol accumulation in ACC (Burns \& Kerppola 2017). This compound is of high interest in the treatment of adrenocortical tumors including ACC.

\section{Tumor models}

A mouse xenograft model of metastatic ACC (Morin et al. 2017) and a transgenic mouse model of metastatic ACC through $\mathrm{P} 53 / \mathrm{Rb}$ inhibition (Batisse-Lignier et al. 2017) were described.

\section{Conclusions}

Clinical and basic research on adrenal tumors is an active field that generated very promising advances during 2017. Prominent examples include an improved understanding of adrenal tumor molecular pathogenesis as well as the introduction of new classifications, molecular markers and tracers for functional imaging. We also highlight international collaboration as a key factor that is likely to accelerate improvements in treatment and outcome of patients with these tumors.

Declaration of interest

J C received lecture honoraria from Novartis.

\section{Funding}

J Cs research position is funded by Akademiska Sjukhuset, Uppsala, Sweden.

\section{References}

Altinmakas E, Hobbs BP, Ye H, Grubbs EG, Perrier ND, Prieto VG, Lee JE \& Ng CS 2017 Diagnostic performance of (18-)F-FDG-PET-CT in adrenal lesions using histopathology as reference standard. Abdominal Radiology 42 577-584. (https://doi.org/10.1007/s00261016-0915-4)

Anderson KL Jr, Thomas SM, Adam MA, Pontius LN, Stang MT, Scheri RP, Roman SA \& Sosa JA 2018 Each procedure matters: threshold for surgeon volume to minimize complications and decrease cost associated with adrenalectomy. Surgery 163 157-164. (https://doi.org/10.1016/j.surg.2017.04.028)

Arlt W, Lang K, Sitch AJ, Dietz AS, Rhayem Y, Bancos I, Feuchtinger A, Chortis V, Gilligan LC, Ludwig P, et al. 2017 Steroid metabolome analysis reveals prevalent glucocorticoid excess in primary aldosteronism. JCI Insight 2 93136. (https://doi.org/10.1172/jci. insight.93136)

Arruda M, Mello Ribeiro Cavalari E, Pessoa de Paula M, Fernandes Cordeiro de Morais F, Furtado Bilro G, Alves Coelho MC, de Oliveira ESdMNA, Choeri D, Moraes A \& Vieira Neto L 2017 The

This work is licensed under a Creative Commons Attribution 4.0 International License. 
presence of nonfunctioning adrenal incidentalomas increases arterial hypertension frequency and severity, and is associated with cortisol levels after dexamethasone suppression test. Journal of Human Hypertension 32 3-11. (https://doi.org/10.1038/s41371-0170011-4)

Asai S, Katabami T, Tsuiki M, Tanaka Y \& Naruse M 2017 Controlling tumor progression with cyclophosphamide, vincristine, and dacarbazine treatment improves survival in patients with metastatic and unresectable malignant pheochromocytomas/paragangliomas. Hormones and Cancer 8 108-118. (https://doi.org/10.1007/s12672017-0284-7)

Assie G, Letouze E, Fassnacht M, Jouinot A, Luscap W, Barreau O, Omeiri H, Rodriguez S, Perlemoine K, Rene-Corail F, et al. 2014 Integrated genomic characterization of adrenocortical carcinoma. Nature Genetics 46 607-612. (https://doi. org/10.1038/ng.2953)

Barthel FP, Wei W, Tang M, Martinez-Ledesma E, Hu X, Amin SB, Akdemir KC, Seth S, Song X, Wang Q, et al. 2017 Systematic analysis of telomere length and somatic alterations in 31 cancer types. Nature Genetics 49 349-357. (https://doi.org/10.1038/ ng.3781)

Batisse-Lignier M, Sahut-Barnola I, Tissier F, Dumontet T, Mathieu M, Drelon C, Pointud JC, Damon-Soubeyrand C, Marceau G, Kemeny JL, et al. 2017 P53/Rb inhibition induces metastatic adrenocortical carcinomas in a preclinical transgenic model. Oncogene 36 4445-4456. (https://doi.org/10.1038/onc.2017.54)

Baur J, Buntemeyer TO, Megerle F, Deutschbein T, Spitzweg C, Quinkler M, Nawroth P, Kroiss M, Germer CT, Fassnacht M, et al. 2017 Outcome after resection of adrenocortical carcinoma liver metastases: a retrospective study. BMC Cancer 17 522. (https://doi. org/10.1186/s12885-017-3506-z)

Bausch B, Schiavi F, Ni Y, Welander J, Patocs A, Ngeow J, Wellner U, Malinoc A, Taschin E, Barbon G, et al. 2017 Clinical characterization of the pheochromocytoma and paraganglioma susceptibility genes SDHA, TMEM127, MAX, and SDHAF2 for gene-informed prevention. JAMA Oncology 3 1204-1212. (https://doi.org/10.1001/ jamaoncol.2017.0223)

Bergman J, Botling J, Fagerberg L, Hallstrom BM, Djureinovic D, Uhlen M \& Ponten F 2017 The human adrenal gland proteome defined by transcriptomics and antibody-based profiling. Endocrinology 158 239-251.

Borges KS, Andrade AF, Silveira VS, Marco Antonio DS, Vasconcelos EJR, Antonini SRR, Tone LG \& Scrideli CA 2017 The aurora kinase inhibitor AMG 900 increases apoptosis and induces chemosensitivity to anticancer drugs in the NCI-H295 adrenocortical carcinoma cell line. Anticancer Drugs 28 634-644. (https://doi.org/10.1097/ CAD.0000000000000504)

Bullova P, Cougnoux A, Marzouca G, Kopacek J \& Pacak K 2017 Bortezomib alone and in combination with salinosporamid a induces apoptosis and promotes pheochromocytoma cell death in vitro and in female nude mice. Endocrinology 158 3097-3108. (https://doi.org/10.1210/en.2017-00592)

Burns VE \& Kerppola TK 2017 ATR-101 inhibits cholesterol efflux and cortisol secretion by ATP-binding cassette transporters, causing cytotoxic cholesterol accumulation in adrenocortical carcinoma cells. British Journal of Pharmacology 174 3315-3332. (https://doi. org/10.1111/bph.13951)

Butz JJ, Yan Q, McKenzie TJ, Weingarten TN, Cavalcante AN, Bancos I, Young WF Jr, Schroeder DR, Martin DP \& Sprung J 2017 Perioperative outcomes of syndromic paraganglioma and pheochromocytoma resection in patients with von Hippel-Lindau disease, multiple endocrine neoplasia type 2, or neurofibromatosis type 1. Surgery 162 1259-1269. (https://doi.org/10.1016/j. surg.2017.08.002)
Cancer Genome Atlas Network 2017 Comprehensive and integrated genomic characterization of adult soft tissue sarcomas. Cell $\mathbf{1 7 1} 950$. e928-965.e928.

Caroccia B, Prisco S, Seccia TM, Piazza M, Maiolino G \& Rossi GP 2017 Macrolides blunt aldosterone biosynthesis: a proof-of-concept study in KCNJ5 mutated adenoma cells ex vivo. Hypertension 70 1238-1242. (https://doi.org/10.1161/

HYPERTENSIONAHA.117.10226)

Cecchetto G, Ganarin A, Bien E, Vorwerk P, Bisogno G, Godzinski J, Dall'Igna P, Reguerre Y, Schneider D, Brugieres L, et al. 2017 Outcome and prognostic factors in high-risk childhood adrenocortical carcinomas: a report from the European Cooperative Study Group on Pediatric Rare Tumors (EXPeRT). Pediatric Blood and Cancer 64 e26368. (https://doi.org/10.1002/pbc.26368)

Chai H, Guo Y, Wang Y \& Zhou G 2017 Automatic computer aided analysis algorithms and system for adrenal tumors on CT images. Technology and Health Care 25 1105-1118. (https://doi.org/10.3233/ THC-160597)

Chomsky-Higgins K, Seib C, Rochefort H, Gosnell J, Shen WT, Kahn JG, Duh QY \& Suh I 2018 Less is more: cost-effectiveness analysis of surveillance strategies for small, nonfunctional, radiographically benign adrenal incidentalomas. Surgery 163 197-204. (https://doi. org/10.1016/j.surg.2017.07.030)

Claps M, Cerri S, Grisanti S, Lazzari B, Ferrari V, Roca E, Perotti P, Terzolo M, Sigala S \& Berruti A 2017 Adding metyrapone to chemotherapy plus mitotane for Cushing's syndrome due to advanced adrenocortical carcinoma. Endocrine [epub]. (https://doi. org/10.1007/s12020-017-1428-9)

Creemers SG, Korpershoek E, Atmodimedjo PN, Dinjens WNM, van Koetsveld PM, Feelders RA \& Hofland LJ 2017 Identification of mutations in cell-free circulating tumor DNA in adrenocortical carcinoma: a case series. Journal of Clinical Endocrinology and Metabolism 102 3611-3615. (https://doi.org/10.1210/jc.2017-00174)

Crona J, Taieb D \& Pacak K 2017 New perspectives on pheochromocytoma and paraganglioma: toward a molecular classification. Endocrine Reviews 38 489-515. (https://doi.org/10.1210/ er.2017-00062)

D'Antongiovanni V, Martinelli S, Richter S, Canu L, Guasti D, Mello T, Romagnoli P, Pacak K, Eisenhofer G, Mannelli M, et al. 2017 The microenvironment induces collective migration in SDHB-silenced mouse pheochromocytoma spheroids. Endocrine-Related Cancer $\mathbf{2 4}$ 555-564. (https://doi.org/10.1530/ERC-17-0212)

Del Valle I, Buonocore F, Duncan AJ, Lin L, Barenco M, Parnaik R, Shah S, Hubank M, Gerrelli D \& Achermann JC 2017 A genomic atlas of human adrenal and gonad development. Wellcome Open Research 2 25. (https://doi.org/10.12688/ wellcomeopenres.11253.1)

Delivanis DA, Bancos I, Atwell TD, Schmit GD, Eiken PW, Natt N, Erickson D, Maraka S, Young WF \& Nathan MA 2018 Diagnostic performance of unenhanced computed tomography and (18) F-fluorodeoxyglucose positron emission tomography in indeterminate adrenal tumours. Clinical Endocrinology 88 30-36. (https://doi.org/10.1111/cen.13448)

Duregon E, Cappellesso R, Maffeis V, Zaggia B, Ventura L, Berruti A, Terzolo M, Fassina A, Volante M \& Papotti M 2017 Validation of the prognostic role of the 'Helsinki Score' in 225 cases of adrenocortical carcinoma. Human Pathology 62 1-7. (https://doi.org/10.1016/j. humpath.2016.09.035)

Dwight T, Flynn A, Amarasinghe K, Benn DE, Lupat R, Li J, Cameron DL, Hogg A, Balachander S, Candiloro ILM, et al. 2018 TERT structural rearrangements in metastatic pheochromocytomas. Endocrine-Related Cancer 25 1-9. (https://doi.org/10.1530/ERC-17-0306)

Eijkelenkamp K, Osinga TE, de Jong MM, Sluiter WJ, Dullaart RP, Links TP, Kerstens MN \& van der Horst-Schrivers AN 2017
This work is licensed under a Creative Commons Attribution 4.0 International License. ded from Bioscientifica.com at $04 / 26 / 2023$ 06:38:33AM 
Calculating the optimal surveillance for head and neck paraganglioma in SDHB-mutation carriers. Familial Cancer 16 123-130. (https://doi.org/10.1007/s10689-016-9923-3)

El Asmar N, Rajpal A, Selman WR \& Arafah BM 2018 The value of perioperative levels of ACTH, DHEA, and DHEA-S and tumor size in predicting recurrence of Cushing disease. Journal of Clinical Endocrinology and Metabolism 103 477-485. (https://doi.org/10.1210/ jc.2017-01797)

Else T, Lerario AM, Everett J, Haymon L, Wham D, Mullane M, Wilson TL, Rainville I, Rana H, Worth AJ, et al. 2017 Adrenocortical carcinoma and succinate dehydrogenase gene mutations: an observational case series. European Journal of Endocrinology 177 439-444. (https://doi.org/10.1530/EJE-17-0358)

Fallo F, Castellano I, Gomez-Sanchez CE, Rhayem Y, Pilon C, Vicennati V, Santini D, Maffeis V, Fassina A, Mulatero P, et al. 2017 Histopathological and genetic characterization of aldosteroneproducing adenomas with concurrent subclinical cortisol hypersecretion: a case series. Endocrine 58 503-512. (https://doi. org/10.1007/s12020-017-1295-4)

Fassnacht M, Arlt W, Bancos I, Dralle H, Newell-Price J, Sahdev A, Tabarin A, Terzolo M, Tsagarakis S \& Dekkers OM 2016 Management of adrenal incidentalomas: European Society of Endocrinology Clinical Practice Guideline in collaboration with the European Network for the Study of Adrenal Tumors. European Journal of Endocrinology 175 G1-G34. (https://doi.org/10.1530/EJE16-0467)

Fiorentini C, Fragni M, Tiberio GAM, Galli D, Roca E, Salvi V, Bosisio D, Missale C, Terzolo M, Memo M, et al. 2018 Palbociclib inhibits proliferation of human adrenocortical tumor cells. Endocrine 59 213-217. (https://doi.org/10.1007/s12020-017-1270-0)

Fishbein L, Ben-Maimon S, Keefe S, Cengel K, Pryma DA, LoaizaBonilla A, Fraker DL, Nathanson KL \& Cohen DL 2017a SDHB mutation carriers with malignant pheochromocytoma respond better to CVD. Endocrine-Related Cancer 24 L51-L55. (https://doi. org/10.1530/ERC-17-0086)

Fishbein L, Leshchiner I, Walter V, Danilova L, Robertson G, Johnson AR, Lichtenberg TM, Murray BA, Ghayee HK, Else T, et al. $2017 b$ Comprehensive molecular characterization of pheochromocytoma and paraganglioma. Cancer Cell 31 1-13.

Flynn A, Dwight T, Benn D, Deb S, Colebatch AJ, Fox S, Harris J, Duncan EL, Robinson B, Hogg A, et al. 2017 Cousins not twins: intratumoural and intertumoural heterogeneity in syndromic neuroendocrine tumours. Journal of Pathology 242 273-283. (https:// doi.org/10.1002/path.4900)

Funder JW, Carey RM, Mantero F, Murad MH, Reincke M, Shibata H, Stowasser M \& Young WF Jr 2016 The management of primary aldosteronism: case detection, diagnosis, and treatment: an Endocrine Society Clinical Practice Guideline. Journal of Clinical Endocrinology and Metabolism 101 1889-1916. (https://doi. org/10.1210/jc.2015-4061)

Furlan A, Dyachuk V, Kastriti ME, Calvo-Enrique L, Abdo H, Hadjab S, Chontorotzea T, Akkuratova N, Usoskin D, Kamenev D, et al. 2017 Multipotent peripheral glial cells generate neuroendocrine cells of the adrenal medulla. Science $\mathbf{3 5 7}$ eaal3753. (https://doi.org/10.1126/ science.aal3753)

Garinet S, Nectoux J, Neou M, Pasmant E, Jouinot A, Sibony M, Orhant L, Pipoli da Fonseca J, Perlemoine K, Bricaire L, et al. 2018 Detection and monitoring of circulating tumor DNA in adrenocortical carcinoma. Endocrine-Related Cancer 25 L13-L17. (https://doi.org/10.1530/ERC-17-0467)

Gaujoux S \& Mihai R 2017 European Society of Endocrine Surgeons (ESES) and European Network for the Study of Adrenal Tumours (ENSAT) recommendations for the surgical management of adrenocortical carcinoma. British Journal of Surgery 104 358-376. (https://doi.org/10.1002/bjs.10414)
Germano A, Rapa I, Duregon E, Votta A, Giorcelli J, Buttigliero C, Scagliotti GV, Volante M, Terzolo M \& Papotti M 2017 Tissue expression and pharmacological in vitro analyses of mTOR and SSTR pathways in adrenocortical carcinoma. Endocrine Pathology $\mathbf{2 8}$ 95-102. (https://doi.org/10.1007/s12022-017-9473-8)

Grocott HP 2017 Safety assessments in the avoidance of preoperative alpha-receptor blockade in phaeochromocytoma surgery: the pitfalls of a zero numerator. British Journal of Anaesthesia 119 545-546. (https://doi.org/10.1093/bja/aex286)

Groeben H, Nottebaum BJ, Alesina PF, Traut A, Neumann HP \& Walz MK 2017 Perioperative alpha-receptor blockade in phaeochromocytoma surgery: an observational case series. British Journal of Anaesthesia 118 182-189. (https://doi.org/10.1093/bja/ aew392)

Guerin C, Pattou F, Brunaud L, Lifante JC, Mirallie E, Haissaguerre M, Huglo D, Olivier P, Houzard C, Ansquer C, et al. 2017 Performance of 18F-FDG PET/CT in the characterization of adrenal masses in noncancer patients: a prospective study. Journal of Clinical Endocrinology and Metabolism 102 2465-2472. (https://doi. org/10.1210/jc.2017-00254)

Hadjadj D, Kim SJ, Denecker T, Ben Driss L, Cadoret JC, Maric C, Baldacci G \& Fauchereau F 2017 A hypothesis-driven approach identifies CDK4 and CDK6 inhibitors as candidate drugs for treatments of adrenocortical carcinomas. Aging 9 2695-2716.

Hadoux J, Terroir M, Leboulleux S, Deschamps F, Al Ghuzlan A, Hescot S, Tselikas L, Borget I, Caramella C, Deandreis D, et al. 2017 Interferon-alpha treatment for disease control in metastatic pheochromocytoma/paraganglioma patients. Hormones and Cancer $\mathbf{8}$ 330-337. (https://doi.org/10.1007/s12672-017-0303-8)

Hamidi O, Young WF Jr, Gruber L, Smestad J, Yan Q, Ponce OJ, Prokop L, Murad MH \& Bancos I 2017a Outcomes of patients with metastatic phaeochromocytoma and paraganglioma: a systematic review and meta-analysis. Clinical Endocrinology 87 440-450. (https:// doi.org/10.1111/cen.13434)

Hamidi O, Young WF Jr, Iniguez-Ariza NM, Kittah NE, Gruber L Bancos C, Tamhane S \& Bancos I 2017b Malignant pheochromocytoma and paraganglioma: 272 patients over 55 years. Journal of Clinical Endocrinology and Metabolism 102 3296-3305. (https://doi.org/10.1210/jc.2017-00992)

Heinze B, Fuss CT, Mulatero P, Beuschlein F, Reincke M, Mustafa M, Schirbel A, Deutschbein T, Williams TA, Rhayem Y, et al. 2018 Targeting CXCR4 (CXC chemokine receptor type 4) for molecular imaging of aldosterone-producing adenoma. Hypertension $\mathbf{7 1}$ 317-325. (https://doi.org/10.1161/ HYPERTENSIONAHA.117.09975)

Henning JEK, Deutschbein T, Altieri B, Steinhauer S, Kircher S, Sbiera S, Wild V, Schlotelburg W, Kroiss M, Perotti P, et al. 2017 Gemcitabinebased chemotherapy in adrenocortical carcinoma: a multicenter study of efficacy and predictive factors. Journal of Clinical Endocrinology and Metabolism 102 4323-4332. (https://doi. org/10.1210/jc.2017-01624)

Hines JM, Bancos I, Bancos C, Singh RD, Avula AV, Young WF, Grebe SK \& Singh RJ 2017 High-resolution, accurate-mass (HRAM) mass spectrometry urine steroid profiling in the diagnosis of adrenal disorders. Clinical Chemistry 63 1824-1835. (https://doi.org/10.1373/ clinchem.2017.271106)

Hoekstra AS, Hensen EF, Jordanova ES, Korpershoek E, van der HorstSchrivers AN, Cornelisse C, Corssmit EP, Hes FJ, Jansen JC, Kunst HP, et al. 2017 Loss of maternal chromosome 11 is a signature event in SDHAF2, SDHD, and VHL-related paragangliomas, but less significant in SDHB-related paragangliomas. Oncotarget 8 1452514536.

Hong AR, Kim JH, Park KS, Kim KY, Lee JH, Kong SH, Lee SY, Shin CS, Kim SW \& Kim SY 2017 Optimal follow-up strategies for adrenal incidentalomas: reappraisal of the 2016 ESE-ENSAT guidelines in real
This work is licensed under a Creative Commons Attribution 4.0 International License. 
clinical practice. European Journal of Endocrinology 177 475-483. (https://doi.org/10.1530/EJE-17-0372)

Janssen I, Blanchet EM, Adams K, Chen CC, Millo C, Herscovitch P, Taieb D, Kebebew E, Lehnert H, Fojo AT, et al. 2015 Superiority of [68Ga]-DOTATATE PET/CT to other functional imaging modalities in the localization of SDHB-associated metastatic pheochromocytoma and paraganglioma. Clinical Cancer Research 21 3888-3895. (https:// doi.org/10.1158/1078-0432.CCR-14-2751)

Janssen I, Chen CC, Taieb D, Patronas NJ, Millo CM, Adams KT, Nambuba J, Herscovitch P, Sadowski SM, Fojo AT, et al. 2016 68Ga-DOTATATE PET/CT in the localization of head and neck paragangliomas compared with other functional imaging modalities and CT/MRI. Journal of Nuclear Medicine 57 186-191. (https://doi. org/10.2967/jnumed.115.161018)

Janssen I, Chen CC, Zhuang Z, Millo CM, Wolf KI, Ling A, Lin FI, Adams KT, Herscovitch P, Feelders RA, et al. 2017 Functional imaging signature of patients presenting with polycythemia/paraganglioma syndromes. Journal of Nuclear Medicine 58 1236-1242. (https://doi. org/10.2967/jnumed.116.187690)

Jasim S, Suman VJ, Jimenez C, Harris P, Sideras K, Burton JK, Worden FP, Auchus RJ \& Bible KC 2017 Phase II trial of pazopanib in advanced/ progressive malignant pheochromocytoma and paraganglioma. Endocrine 57 220-225. (https://doi.org/10.1007/s12020-017-1359-5)

Jha A, Ling A, Millo C, Gupta G, Viana B, Lin FI, Herscovitch P, Adams KT, Taieb D, Metwalli AR, et al. 2017 Superiority of (68) Ga-DOTATATE over (18)F-FDG and anatomic imaging in the detection of succinate dehydrogenase mutation (SDHx)-related pheochromocytoma and paraganglioma in the pediatric population. European Journal of Nuclear Medicine and Molecular Imaging 45 787-797. (https://doi.org/10.1007/s00259-017-3896-9)

Jimenez C, Libutti SK, Landry CS, Lloyd RV, McKay RR, Rohren E, Seethala RR, Wang TS, Chen H \& Perrier ND 2017 AJCC Cancer Staging Manual, 8th ed., pp 919-927. Eds MB Amin, S Edge, F Greene, DR Byrd, RK Brookland, MK Washington, JE Gershenwald, CC Compton, KR Hess, DC Sullivan, et al. New York, NY, USA: Springer.

Jochmanova I, Wolf KI, King KS, Nambuba J, Wesley R, Martucci V, Raygada M, Adams KT, Prodanov T, Fojo AT, et al. 2017 SDHB-related pheochromocytoma and paraganglioma penetrance and genotypephenotype correlations. Journal of Cancer Research and Clinical Oncology 143 1421-1435. (https://doi.org/10.1007/s00432-017-2397-3)

Jouinot A, Assie G, Libe R, Fassnacht M, Papathomas T, Barreau O, de la Villeon B, Faillot S, Hamzaoui N, Neou M, et al. 2017 DNA methylation is an independent prognostic marker of survival in adrenocortical cancer. Journal of Clinical Endocrinology and Metabolism 102 923-932.

Kallenberg FGJ, Bastiaansen BAJ, Nio CY, Soeters MR, Boermeester MA, Aalfs CM, Bossuyt PMM \& Dekker E 2017 Adrenal lesions in patients with (attenuated) familial adenomatous polyposis and MUTYHassociated polyposis. Diseases of the Colon and Rectum 60 1057-1064. (https://doi.org/10.1097/DCR.0000000000000809)

Kim BJ, Kwak MK, Ahn SH, Kim H, Lee SH \& Koh JM 2018 Lower trabecular bone score in patients with primary aldosteronism: human skeletal deterioration by aldosterone excess. Journal of Clinical Endocrinology and Metabolism 103 615-621. (https://doi. org/10.1210/jc.2017-02043)

Kitamoto T, Omura M, Suematsu S, Saito J \& Nishikawa T 2018 KCNJ5 mutation as a predictor for resolution of hypertension after surgical treatment of aldosterone-producing adenoma. Journal of Hypertension 36 619-627. (https://doi.org/10.1097/ HJH.0000000000001578)

Kobuke K, Oki K, Gomez-Sanchez CE, Gomez-Sanchez EP, Ohno H, Itcho K, Yoshii Y, Yoneda M \& Hattori N 2018 Calneuron 1 increased $\mathrm{Ca}(2+)$ in the endoplasmic reticulum and aldosterone production in aldosterone-producing adenoma. Hypertension 71 125-133. (https:// doi.org/10.1161/HYPERTENSIONAHA.117.10205)
Koh JM, Ahn SH, Kim H, Kim BJ, Sung TY, Kim YH, Hong SJ, Song DE \& Lee SH 2017 Validation of pathological grading systems for predicting metastatic potential in pheochromocytoma and paraganglioma. PLoS ONE 12 e0187398. (https://doi.org/10.1371/ journal.pone.0187398)

Kometani M, Yoneda T, Demura M, Koide H, Nishimoto K, Mukai K, Gomez-Sanchez CE, Akagi T, Yokota T, Horike SI, et al. 2017 Cortisol overproduction results from DNA methylation of CYP11B1 in hypercortisolemia. Scientific Reports 7 11205. (https://doi. org/10.1038/s41598-017-11435-2)

Kong G, Grozinsky-Glasberg S, Hofman MS, Callahan J, Meirovitz A, Maimon O, Pattison DA, Gross DJ \& Hicks RJ 2017 Efficacy of peptide receptor radionuclide therapy for functional metastatic paraganglioma and pheochromocytoma. Journal of Clinical Endocrinology and Metabolism 102 3278-3287. (https://doi. org/10.1210/jc.2017-00816)

Kuai R, Subramanian C, White PT, Timmermann BN, Moon JJ, Cohen MS \& Schwendeman A 2017 Synthetic high-density lipoprotein nanodisks for targeted withalongolide delivery to adrenocortical carcinoma. International Journal of Nanomedicine $\mathbf{1 2}$ 6581-6594. (https://doi.org/10.2147/IJN.S140591)

Lam AK 2017 Update on adrenal tumours in 2017 World Health Organization (WHO) of Endocrine Tumours. Endocrine Pathology 28 213-227. (https://doi.org/10.1007/s12022-017-9484-5)

Laufs V, Altieri B, Sbiera S, Kircher S, Steinhauer S, Beuschlein F, Quinkler M, Willenberg HS, Rosenwald A, Fassnacht M, et al. 2018 ERCC1 as predictive biomarker to platinum-based chemotherapy in adrenocortical carcinomas. European Journal of Endocrinology 178 183-190. (https://doi.org/10.1530/EJE-17-0788)

Lecoq AL, Stratakis CA, Viengchareun S, Chaligne R, Tosca L, Demeocq V, Hage M, Berthon A, Faucz FR, Hanna P, et al. 2017 Adrenal GIPR expression and chromosome 19q13 microduplications in GIP-dependent Cushing's syndrome. JCI Insight 2 92184. (https:// doi.org/10.1172/jci.insight.92184)

Lenders JW, Duh QY, Eisenhofer G, Gimenez-Roqueplo AP, Grebe SK, Murad MH, Naruse M, Pacak K \& Young WF Jr 2014 Pheochromocytoma and paraganglioma: an endocrine society clinical practice guideline. Journal of Clinical Endocrinology and Metabolism 99 1915-1942. (https://doi.org/10.1210/jc.2014-1498)

Lian J, Lin D, Xie X, Xu Y, Xu L, Meng L \& Zhu Y 2017 NVP-AUY922, a novel HSP90 inhibitor, inhibits the progression of malignant pheochromocytoma in vitro and in vivo. OncoTargets and Therapy 10 2219-2226. (https://doi.org/10.2147/OTT.S130236)

Lloyd RV, Osamura RY, Kloppel G \& Rosai J 2017 WHO Classification of Tumours: Pathology and Genetics of Tumours of Endocrine Organs. Lyon, France: IARC Press.

Maiolino G, Rossitto G, Bisogni V, Cesari M, Seccia TM, Plebani M \& Rossi GP 2017 Quantitative value of aldosterone-renin ratio for detection of aldosterone-producing adenoma: the Aldosterone-Renin Ratio for Primary Aldosteronism (AQUARR) study. Journal of the American Heart Association 6 e005574. (https://doi.org/10.1161/ JAHA.117.005574)

Majtan B, Zelinka T, Rosa J, Petrak O, Kratka Z, Strauch B, Tuka V, Vrankova A, Michalsky D, Novak K, et al. 2017 Long-term effect of adrenalectomy on cardiovascular remodeling in patients with pheochromocytoma. Journal of Clinical Endocrinology and Metabolism 102 1208-1217.

Maniero C, Garg S, Zhao W, Johnson TI, Zhou J, Gurnell M \& Brown MJ 2017 NEFM (neurofilament medium) polypeptide, a marker for zona glomerulosa cells in human adrenal, inhibits D1R (dopamine D1 receptor)-mediated secretion of aldosterone. Hypertension $\mathbf{7 0}$ 357-364. (https://doi.org/10.1161/HYPERTENSIONAHA.117.09231)

Martincorena I, Raine KM, Gerstung M, Dawson KJ, Haase K, Van Loo P, Davies H, Stratton MR \& Campbell PJ 2017 Universal patterns of selection in cancer and somatic tissues. Cell 171 1029.e1021-1041. e1021. (https://doi.org/10.1016/j.cell.2017.09.042) 
Mayo-Smith WW, Song JH, Boland GL, Francis IR, Israel GM, Mazzaglia PJ, Berland LL \& Pandharipande PV 2017 Management of incidental adrenal masses: a white paper of the ACR Incidental Findings Committee. Journal of the American College of Radiology $\mathbf{1 4}$ 1038-1044. (https://doi.org/10.1016/j.jacr.2017.05.001)

Mete O, Gucer H, Kefeli M \& Asa SL 2018 Diagnostic and prognostic biomarkers of adrenal cortical carcinoma. American Journal of Surgical Pathology 42 201-213. (https://doi.org/10.1097/ PAS.0000000000000943)

Monticone S, Burrello J, Tizzani D, Bertello C, Viola A, Buffolo F, Gabetti L, Mengozzi G, Williams TA, Rabbia F, et al. 2017 Prevalence and clinical manifestations of primary aldosteronism encountered in primary care practice. Journal of the American College of Cardiology 69 1811-1820. (https://doi.org/10.1016/j.jacc.2017.01.052)

Monticone S, D'Ascenzo F, Moretti C, Williams TA, Veglio F, Gaita F \& Mulatero P 2018 Cardiovascular events and target organ damage in primary aldosteronism compared with essential hypertension: a systematic review and meta-analysis. Lancet Diabetes and Endocrinology 6 41-50. (https://doi.org/10.1016/S22138587(17)30319-4)

Morin A, Ruggiero C, Robidel E, Doghman-Bouguerra M, Das AT, Castellano R, Josselin E, Favier J \& Lalli E 2017 Establishment of a mouse xenograft model of metastatic adrenocortical carcinoma. Oncotarget 8 51050-51057.

Muller M, Ferlicot S, Guillaud-Bataille M, Le Teuff G, Genestie C, Deveaux S, Slama A, Poulalhon N, Escudier B, Albiges L, et al. 2017 Reassessing the clinical spectrum associated with hereditary leiomyomatosis and renal cell carcinoma syndrome in French FH mutation carriers. Clinical Genetics 92 606-615. (https://doi. org/10.1111/cge.13014)

Murakami M, Yoshimoto T, Nakabayashi K, Nakano Y, Fukaishi T, Tsuchiya K, Minami I, Bouchi R, Okamura K, Fujii Y, et al. 2017 Molecular characteristics of the KCNJ5 mutated aldosteroneproducing adenomas. Endocrine-Related Cancer 24 531-541. (https:// doi.org/10.1530/ERC-17-0117)

Nanba AT, Nanba K, Byrd JB, Shields JJ, Giordano TJ, Miller BS, Rainey WE, Auchus RJ \& Turcu AF 2017 Discordance between imaging and immunohistochemistry in unilateral primary aldosteronism. Clinical Endocrinology 87 665-672. (https://doi. org/10.1111/cen.13442)

Nastos K, Cheung VTF, Toumpanakis C, Navalkissoor S, Quigley AM, Caplin M \& Khoo B 2017 Peptide Receptor Radionuclide Treatment and (131)I-MIBG in the management of patients with metastatic/ progressive phaeochromocytomas and paragangliomas. Journal of Surgical Oncology 115 425-434. (https://doi.org/10.1002/jso.24553)

Nieman LK, Biller BM, Findling JW, Newell-Price J, Savage MO, Stewart PM \& Montori VM 2008 The diagnosis of Cushing's syndrome: an Endocrine Society Clinical Practice Guideline. Journal of Clinical Endocrinology and Metabolism 93 1526-1540. (https://doi. org/10.1210/jc.2008-0125)

Nieman LK, Biller BM, Findling JW, Murad MH, Newell-Price J, Savage MO \& Tabarin A 2015 Treatment of Cushing's syndrome: an Endocrine Society Clinical Practice Guideline. Journal of Clinical Endocrinology and Metabolism 100 2807-2831. (https://doi. org/10.1210/jc.2015-1818)

Nishimoto K, Koga M, Seki T, Oki K, Gomez-Sanchez EP, GomezSanchez CE, Naruse M, Sakaguchi T, Morita S, Kosaka T, et al. 2017 Immunohistochemistry of aldosterone synthase leads the way to the pathogenesis of primary aldosteronism. Molecular and Cellular Endocrinology 441 124-133. (https://doi.org/10.1016/j. mce.2016.10.014)

Nockel P, El Lakis M, Gaitanidis A, Yang L, Merkel R, Patel D, Nilubol N Prodanov T, Pacak K \& Kebebew E 2018 Preoperative genetic testing in pheochromocytomas and paragangliomas influences the surgical approach and the extent of adrenal surgery. Surgery 163 191-196. (https://doi.org/10.1016/j.surg.2017.05.025)
Noto RB, Pryma DA, Jensen J, Lin T, Stambler N, Strack T, Wong V \& Goldsmith SJ 2018 Phase 1 study of high-specific-activity I-131 MIBG for metastatic and/or recurrent pheochromocytoma or paraganglioma. Journal of Clinical Endocrinology and Metabolism 103 213-220. (https://doi.org/10.1210/jc.2017-02030)

Omata K, Anand SK, Hovelson DH, Liu CJ, Yamazaki Y, Nakamura Y, Ito S, Satoh F, Sasano H, Rainey WE, et al. 2017a Aldosterone-producing cell clusters frequently harbor somatic mutations and accumulate with age in normal adrenals. Journal of the Endocrine Society 1 787-799. (https://doi.org/10.1210/ js.2017-00134)

Omata K, Yamazaki Y, Nakamura Y, Anand SK, Barletta JA, Sasano H, Rainey WE, Tomlins SA \& Vaidya A 2017b Genetic and histopathologic intertumor heterogeneity in primary aldosteronism. Journal of Clinical Endocrinology and Metabolism 102 1792-1796. (https://doi.org/10.1210/jc.2016-4007)

Oudijk L, Papathomas T, de Krijger R, Korpershoek E, GimenezRoqueplo AP, Favier J, Canu L, Mannelli M, Rapa I, Curras-Freixes M, et al. 2017 The mTORC1 complex is significantly overactivated in SDHX-mutated paragangliomas. Neuroendocrinology 105 384-393. (https://doi.org/10.1159/000455864)

Pandit-Taskar N, Zanzonico P, Staton KD, Carrasquillo JA, ReidyLagunes D, Lyashchenko S, Burnazi E, Zhang H, Lewis JS, Blasberg R, et al. 2018 Biodistribution and dosimetry of (18) F-meta-fluorobenzylguanidine: a first-in-human PET/CT imaging study of patients with neuroendocrine malignancies. Journal of Nuclear Medicine 59 147-153. (https://doi.org/10.2967/ jnumed.117.193169)

Pang Y, Yang C, Schovanek J, Wang H, Bullova P, Caisova V, Gupta G, Wolf KI, Semenza GL, Zhuang Z, et al. 2017 Anthracyclines suppress pheochromocytoma cell characteristics, including metastasis, through inhibition of the hypoxia signaling pathway. Oncotarget 8 22313-22324.

Papadopoulos KP, El-Rayes BF, Tolcher AW, Patnaik A, Rasco DW, Harvey RD, LoRusso PM, Sachdev JC, Abbadessa G, Savage RE, et al. 2017 A Phase 1 study of ARQ 087, an oral pan-FGFR inhibitor in patients with advanced solid tumours. British Journal of Cancer 117 1592-1599. (https://doi.org/10.1038/bjc.2017.330)

Parikh PP, Rubio GA, Farra JC \& Lew JI 2017 Nationwide review of hormonally active adrenal tumors highlights high morbidity in pheochromocytoma. Journal of Surgical Research 215 204-210. (https://doi.org/10.1016/j.jss.2017.04.011)

Patel D, Thompson MD, Manna SK, Krausz KW, Zhang L, Nilubol N, Gonzalez FJ \& Kebebew E 2017 Unique and novel urinary metabolomic features in malignant versus benign adrenal neoplasms. Clinical Cancer Research 23 5302-5310. (https://doi. org/10.1158/1078-0432.CCR-16-3156)

Patrova J, Kjellman M, Wahrenberg H \& Falhammar H 2017 Increased mortality in patients with adrenal incidentalomas and autonomous cortisol secretion: a 13-year retrospective study from one center. Endocrine 58 267-275. (https://doi.org/10.1007/s12020017-1400-8)

Perge P, Butz H, Pezzani R, Bancos I, Nagy Z, Paloczi K, Nyiro G, Decmann A, Pap E, Luconi M, et al. 2017 Evaluation and diagnostic potential of circulating extracellular vesicle-associated microRNAs in adrenocortical tumors. Scientific Reports 7 5474. (https://doi. org/10.1038/s41598-017-05777-0)

Pilati C, Shinde J, Alexandrov LB, Assie G, Andre T, Helias-Rodzewicz Z, Ducoudray R, Le Corre D, Zucman-Rossi J, Emile JF, et al. 2017 Mutational signature analysis identifies MUTYH deficiency in colorectal cancers and adrenocortical carcinomas. Journal of Pathology 242 10-15. (https://doi.org/10.1002/path.4880)

Pinto EM, Rodriguez-Galindo C, Pounds SB, Wang L, Clay MR, Neale G, Garfinkle EAR, Lam CG, Levy CF, Pappo AS, et al. 2017 Identification of clinical and biologic correlates associated with outcome in children with adrenocortical tumors without germline TP53

This work is licensed under a Creative Commons Attribution 4.0 International License. 
mutations: a St Jude Adrenocortical Tumor Registry and Children's Oncology Group Study. Journal of Clinical Oncology 35 3956-3963. (https://doi.org/10.1200/JCO.2017.74.2460)

Plouin PF, Amar L, Dekkers OM, Fassnacht M, Gimenez-Roqueplo AP, Lenders JW, Lussey-Lepoutre C \& Steichen O 2016 European Society of Endocrinology Clinical Practice Guideline for long-term follow-up of patients operated on for a phaeochromocytoma or a paraganglioma. European Journal of Endocrinology 174 G1-G10. (https://doi.org/10.1530/EJE-16-0033)

Poorman CE, Postlewait LM, Ethun CG, Tran TB, Prescott JD, Pawlik TM, Wang TS, Glenn J, Hatzaras I, Shenoy R, et al. 2017 Blood transfusion and survival for resected adrenocortical carcinoma: a study from the United States Adrenocortical Carcinoma Group. American Surgeon 83 761-768.

Poorman CE, Ethun CG, Postlewait LM, Tran TB, Prescott JD, Pawlik TM, Wang TS, Glenn J, Hatzaras I, Shenoy R, et al. 2018 A novel T-stage classification system for adrenocortical carcinoma: proposal from the US Adrenocortical Carcinoma Study Group. Annals of Surgical Oncology 25 520-527. (https://doi.org/10.1245/ s10434-017-6236-1)

Powers JF, Pacak K \& Tischler AS 2017 Pathology of human pheochromocytoma and paraganglioma xenografts in NSG mice. Endocrine Pathology 28 2-6. (https://doi.org/10.1007/s12022-0169452-5)

Rednam SP, Erez A, Druker H, Janeway KA, Kamihara J, Kohlmann WK, Nathanson KL, States LJ, Tomlinson GE, Villani A, et al. 2017 Von Hippel-Lindau and Hereditary Pheochromocytoma/Paraganglioma Syndromes: clinical features, genetics, and surveillance recommendations in childhood. Clinical Cancer Research 23 e68-e75. (https://doi.org/10.1158/1078-0432.CCR-17-0547)

Rijken JA, Niemeijer ND, Jonker MA, Eijkelenkamp K, Jansen JC, van Berkel A, Timmers H, Kunst HPM, Bisschop P, Kerstens MN, et al. 2018 The penetrance of paraganglioma and pheochromocytoma in SDHB germline mutation carriers. Clinical Genetics 93 60-66. (https://doi.org/10.1111/cge.13055)

Roca E, Berruti A, Sbiera S, Rapa I, Oneda E, Sperone P, Ronchi CL, Ferrari L, Grisanti S, Germano A, et al. 2017 Topoisomerase 2alpha and thymidylate synthase expression in adrenocortical cancer. Endocrine-Related Cancer 24 299-307. (https://doi.org/10.1530/ERC17-0095)

Roman-Gonzalez A \& Jimenez C 2017 Malignant pheochromocytomaparaganglioma: pathogenesis, TNM staging, and current clinical trials. Current Opinion in Endocrinology, Diabetes and Obesity 24 174-183. (https://doi.org/10.1097/MED.0000000000000330)

Roman-Gonzalez A, Zhou S, Ayala-Ramirez M, Shen C, Waguespack SG, Habra MA, Karam JA, Perrier N, Wood CG \& Jimenez C 2017 Impact of surgical resection of the primary tumor on overall survival in patients with metastatic pheochromocytoma or sympathetic paraganglioma. Annals of Surgery [epub]. (https://doi.org/10.1097/ SLA.0000000000002195)

Ruggiero C, Doghman-Bouguerra M, Sbiera S, Sbiera I, Parsons M, Ragazzon B, Morin A, Robidel E, Favier J, Bertherat J, et al. 2017 Dosage-dependent regulation of VAV2 expression by steroidogenic factor-1 drives adrenocortical carcinoma cell invasion. Science Signaling 10 eaal2464. (https://doi.org/10.1126/ scisignal.aal2464)

Sbiera S, Sbiera I, Ruggiero C, Doghman-Bouguerra M, Korpershoek E, de Krijger RR, Ettaieb H, Haak H, Volante M, Papotti M, et al. 2017 Assessment of VAV2 expression refines prognostic prediction in adrenocortical carcinoma. Journal of Clinical Endocrinology and Metabolism 102 3491-3498. (https://doi.org/10.1210/jc.201700984)

Scholl UI, Abriola L, Zhang C, Reimer EN, Plummer M, Kazmierczak BI, Zhang J, Hoyer D, Merkel JS, Wang W, et al. 2017 Macrolides selectively inhibit mutant KCNJ5 potassium channels that cause aldosterone-producing adenoma. Journal of Clinical Investigation 127 2739-2750. (https://doi.org/10.1172/JCI91733)

Scortegagna M, Berthon A, Settas N, Giannakou A, Garcia G, Li JL, James B, Liddington RC, Vilches-Moure JG, Stratakis CA, et al. 2017 The E3 ubiquitin ligase Siah1 regulates adrenal gland organization and aldosterone secretion. JCI Insight 2 97128. (https://doi. org/10.1172/jci.insight.97128)

Svahn F, Juhlin CC, Paulsson JO, Fotouhi O, Zedenius J, Larsson C \& Stenman A 2018 Telomerase reverse transcriptase promoter hypermethylation is associated with metastatic disease in abdominal paraganglioma. Clinical Endocrinology 88 343-345. (https://doi. org/10.1111/cen.13513)

Tan GC, Negro G, Pinggera A, Tizen Laim NMS, Mohamed Rose I, Ceral J, Ryska A, Chin LK, Kamaruddin NA, Mohd Mokhtar N, et al. 2017 Aldosterone-producing adenomas: histopathology-genotype correlation and identification of a novel CACNA1D mutation. Hypertension 70 129-136. (https://doi.org/10.1161/ HYPERTENSIONAHA.117.09057)

Taylor DR, Ghataore L, Couchman L, Vincent RP, Whitelaw B, Lewis D, Diaz-Cano S, Galata G, Schulte KM, Aylwin S, et al. 2017 A 13-steroid serum panel based on LC-MS/MS: use in detection of adrenocortical carcinoma. Clinical Chemistry 63 1836-1846. (https:// doi.org/10.1373/clinchem.2017.277624)

Toledo RA, Burnichon N, Cascon A, Benn DE, Bayley JP, Welander J, Tops CM, Firth H, Dwight T, Ercolino T, et al. 2017 Consensus statement on next-generation-sequencing-based diagnostic testing of hereditary phaeochromocytomas and paragangliomas. Nature Reviews Endocrinology 13 233-247. (https://doi.org/10.1038/ nrendo.2016.185)

Tufton N, Shapiro L, Srirangalingam U, Richards P, Sahdev A, Kumar AV, McAndrew L, Martin L, Berney D, Monson J, et al. 2017 Outcomes of annual surveillance imaging in an adult and paediatric cohort of succinate dehydrogenase B mutation carriers. Clinical Endocrinology 86 286-296. (https://doi.org/10.1111/cen.13246)

van der Tuin $\mathrm{K}$, Mensenkamp AR, Tops CMJ, Corssmit EPM, Dinjens WN, van de Horst-Schrivers AN, Jansen JC, de Jong MM, Kunst HPM, Kusters B, et al. 2018 Clinical aspects of SDHA-related pheochromocytoma and paraganglioma: a nationwide study. Journal of Clinical Endocrinology and Metabolism 103 438-445. (https://doi. org/10.1210/jc.2017-01762)

Velema M, Dekkers T, Hermus A, Timmers H, Lenders J, Groenewoud H, Schultze Kool L, Langenhuijsen J, Prejbisz A, van der Wilt GJ, et al. 2018 Quality of life in primary aldosteronism: a comparative effectiveness study of adrenalectomy and medical treatment. Journal of Clinical Endocrinology and Metabolism 103 16-24.

Vezzosi D, Do Cao C, Hescot S, Bertherat J, Haissaguerre M, Bongard V, Drui D, De La Fouchardiere C, Illouz F, Borson-Chazot F, et al. 2018 Time until partial response in metastatic adrenocortical carcinoma long-term survivors. Hormones and Cancer 9 62-69. (https://doi. org/10.1007/s12672-017-0313-6)

Weigand I, Ronchi CL, Rizk-Rabin M, Dalmazi GD, Wild V, Bathon K, Rubin B, Calebiro D, Beuschlein F, Bertherat J, et al. 2017 Differential expression of the protein kinase A subunits in normal adrenal glands and adrenocortical adenomas. Scientific Reports 7 49. (https://doi. org/10.1038/s41598-017-00125-8)

Welander J, Lysiak M, Brauckhoff M, Brunaud L, Soderkvist P \& Gimm O 2018 Activating FGFR1 mutations in sporadic pheochromocytomas. World Journal of Surgery 42 482-489. (https:// doi.org/10.1007/s00268-017-4320-0)

Williams MD \& Tischler AS 2017 Update from the 4th edition of the World Health Organization classification of head and neck tumours: paragangliomas. Head and Neck Pathology 11 88-95. (https://doi. org/10.1007/s12105-017-0786-1)
This work is licensed under a Creative Commons Attribution 4.0 International License. ded from Bioscientifica.com at 04/26/2023 06:38:33AM 
Wu VC, Wang SM, Chueh SJ, Yang SY, Huang KH, Lin YH, Wang JJ, Connolly R, Hu YH, Gomez-Sanchez CE, et al. 2017 The prevalence of CTNNB1 mutations in primary aldosteronism and consequences for clinical outcomes. Scientific Reports 7 39121. (https://doi. org/10.1038/srep39121)

Yamazaki Y, Nakamura Y, Omata K, Ise K, Tezuka Y, Ono Y, Morimoto R, Nozawa Y, Gomez-Sanchez CE, Tomlins SA, et al. 2017

Histopathological classification of cross-sectional image-negative hyperaldosteronism. Journal of Clinical Endocrinology and Metabolism 102 1182-1192.

Yener S, Baris M, Peker A, Demir O, Ozgen B \& Secil M 2017 Autonomous cortisol secretion in adrenal incidentalomas and increased visceral fat accumulation during follow-up. Clinical Endocrinology 87 425-432. (https://doi.org/10.1111/ cen.13408)

Young JWF, Calhoun DA, Lenders JWM, Stowasser M \& Textor SC 2017 Screening for endocrine hypertension: an Endocrine Society
Scientific Statement. Endocrine Reviews 38 103-122. (https://doi. org/10.1210/er.2017-00054)

Zennaro MC, Boulkroun S \& Fernandes-Rosa F 2017 Genetic causes of functional adrenocortical adenomas. Endocrine Reviews 38 516-537. (https://doi.org/10.1210/er.2017-00189)

Zhang R, Gupta D \& Albert SG 2017 Pheochromocytoma as a reversible cause of cardiomyopathy: analysis and review of the literature. International Journal of Cardiology 249 319-323. (https://doi. org/10.1016/j.ijcard.2017.07.014)

Zheng S, Cherniack AD, Dewal N, Moffitt RA, Danilova L, Murray BA, Lerario AM, Else T, Knijnenburg TA, Ciriello G, et al. 2016 Comprehensive pan-genomic characterization of adrenocortical carcinoma. Cancer Cell 29 723-736. (https://doi.org/10.1016/j. ccell.2016.04.002)

Zhu Y, Wang M, Zhao X, Zhang L, Wu Y, Wang B \& Hu W 2017 Rottlerin as a novel chemotherapy agent for adrenocortical carcinoma. Oncotarget 8 22825-22834.

Received in final form 19 April 2018

Accepted 24 April 2018
() 2018 The authors Published by Bioscientifica Ltd. Printed in Great Britain
This work is licensed under a Creative Commons Attribution 4.0 International License.

ded from Bioscientifica.com at 04/26/2023 06:38:33AM via free access 